UDK: 821.131.1.09-32 Bontempelli M.

Izvorni znanstveni članak

Primljen 15. I. 2020.

Sandra Milanko

Sveučilište u Zadru, Odjel za talijanistiku

smilanko@unizd.hr

\title{
BONTEMPELLI HUMORIST I ZBIRKA KRATKIH PRIČA L'EDEN DELLA TARTARUGA
}

\section{Sažetak}

Poznat prvenstveno kao začetnik talijanskoga magičnog realizma, talijanski književnik Massimo Bontempelli (1878. - 1960.) u užim književnim i kritičkim kuloarima 20. stoljeća pamti se i po istančanoj humorističkoj veni koja će kroz ironiju, parodiju, satiru, pa čak i grotesku, pratiti cijeli njegov književni i publicistički rad. Počevši od prve zbirke kratkih priča Socrate moderno (1908.), pa sve do zrelijih književnih ostvarenja između dvadesetih i tridesetih godina, Bontempelli će njegovati i usavršavati svoj humoristički izraz. U prilog tomu govori ne samo njegov književni opus iz toga razdoblja, panoramski izložen kroz prizmu humorizma, već i vrlo rijetka i od kritike zaboravljena zbirka kratkih priča $L^{\prime} E d e n$ della tartaruga (1926.) s kojom je sudjelovao u zanimljivome izdavačkom eksperimentu, biblioteci Umorismo italiano. Serie del fauno giallo Giuseppea Zucce. Zbirka se u drugome dijelu članka detaljno opisuje i smješta unutar njegova opusa otkrivajući da iza nje stoji Bontempellijev izdavački pothvat: spajanje objavljenih i neobjavljenih kratkih priča u svrhu povezivanja prethodnih i sljedećih književnih djela u svojevrsni makrotekst.

Ključne riječi: humorizam; ironija; parodija; magični realizam; kratka priča; biblioteka 
Na pitanje Giuseppea Zucce, urednika biblioteke Umorismo italiano. Serie del fauno giallo (Talijanski humorizam. Biblioteka žutog fauna) i osnivača nakladničke kuće Il Fauno: „Što je to, po vama, humor?“, Massimo Bontempelli odgovorio je na sebi svojstven, bontempelijevski način: „Humorizam je jedini način da nas ne shvate ozbiljno i onda kad govorimo o ozbiljnim stvarima: to je piščev ideal."

Može se tvrditi da je ne biti shvaćen ozbiljno i kada se govori o ozbiljnim stvarima jedna od misli vodilja začetnika talijanskoga magičnog realizma još od njegovih književnih početaka obilježenih prvom zbirkom kratkih priča Socrate moderno (Moderni Sokrat). Prisjećajući se svoga četverogodišnjeg učiteljskog iskustva u provincijskim gradićima Italije na početku 20. stoljeća, Bontempelli satirizira figuru učitelja, odnosno različite tipove modernoga Sokrata, bačene u ralje koruptivnoga obrazovnog sustava i njegova neučinkovitog birokratskog aparata, koji sporo umiru unatoč ispijanju državne kukute, ,jer im ju država daje u suviše malim dozama! ${ }^{\alpha_{2}}$ Bontempelli se usput obrušava i na konvencije i sustav vrijednosti talijanskoga provincijskog malograđanstva, karijerizam, pa čak i masonstvo, s očekivanim humorističkim učinkom. ${ }^{3}$ Bontempellijev humor, koji se u većem dijelu njegova opusa javlja u obliku ironije, satire, parodije, apsurda te groteske, dade se primijetiti i u njegovu publicističkom radu. Najreprezentativniji primjer u tome pogledu predstavlja niz članaka s kojima Bontempelli sudjeluje u takozvanoj kardučijevskoj polemici (la polemica carducciana) u kojoj su se suprotstavili osporavatelji i branitelji Carduccijeva kritičarskog rada. Polemičari priklonjeni Croceovu osporavateljskom stajalištu nadjenuli su mu nadimak „humorist" aludirajući, kako primjećuje Simona Cigliana, na njegovu tobožnju „nesposobnost da sudjeluje u raspravi.“4 Bontempelli je, naime, „navukavši ruho razigranog i slobodoumnog golijarda usmjerio [...]

Massimo Bontempelli, L'Eden della tartaruga, Edizioni d'arte Fauno, Roma, 1926. Svi citati i naslovi u članku prijevod su s talijanskoga autorice članka.

2 Massimo Bontempelli, Socrate moderno, Lattes, Torino, 1908., str. VII.

3 Vidi Giuseppe Lipparini, „Romanzi e novelle“, Il Marzocco, Firenca, god. XIII., br. 27., 5. srpnja 1908., str. 2.

4 Simona Cigliana, „Gli antidoti della ragione: classicismo, ironia e metafisica“, Bollettino '9oo, br. 1. - 2., 2010., <https://boll9oo.it/numeri/2010-i/Cigliana.html>, (14. I. 2020.). 
urnebesno smiješne crtice ${ }^{\text {" }}$ protiv pojedinih sudionika polemike poput Goffreda Belloncija ${ }^{6}$, pa i samoga Crocea i njegove estetike, analizirajući na kročeanski način, ali u parodijskome ključu, dječju pjesmicu La vispa Teresa (Živahna Tereza). ${ }^{7}$

Crvena nit satire i parodije prožima i sljedeću zbirku kratkih priča ironična naslova Sette savi (Sedam mudraca) jer se iza njih krije sedam mentalno poremećenih likova koji gaje filozofske ambicije. Opsjednuti silogizmima i filozofemima koje bi htjeli primijeniti na vlastiti život, svi njihovi pokušaji propadnu u sudaru sa stvarnošću i društvenim konvencijama. Primjećuje, dapače, Walter Pedullà da se radi o „idejama kao paradoksima koji eksplodiraju kad se sudare stvarnost i logika: riječ je o dvjema razinama koje se nažalost ne smiju miješati i koje su nepomirljive. I bolje, jer se tako ima čemu smijati, smijati do mile volje." ${ }^{\text {"8 }}$ Bontempellijevom se humorizmu stoga može dodati smisao za paradoks $i$ apsurd, karakteristike koje će ga, zajedno s porivom za obnovom umjetničkoga izraza i interventizmom, približiti futurizmu. I Bontempelli će se, baš poput dobra dijela futurista, pridružiti vrjednovanju varijetea i café-chantanta diveći se, na primjer, izvedbenoj umjetnosti talijanskoga glumca i zabavljača Ettorea Petrolinija:

Petrolini se rodio u café-chantantu i café-chantant je njegov dominij.

No njegova umjetnost to nadilazi.

U posljednje vrijeme njegove kreacije, no točnije bi bilo reći njegova otkrića, postale su nevjerojatno moćne.

Unio je u Kazalište jedan novi element: grotesku koju dovodi do neviđenih visina.

Veći dio naše publike, koji robuje konstantno obnavljajućoj i nepredvidljivoj komičnosti, percipira, rekli bismo, samo najsmješnije i najsočnije obrise njegove polemične umjetnosti. Naviknuvši se gledati na varijete

\section{Isto.}

6 Vidi M. [Assimo] B. [ontempelli], „La festuca“, Le Cronache Letterarie, Firenca, god. II., br. 54., 26. veljače 1911., str. 3., Fernando Tempesti, Massimo Bontempelli, La Nuova Italia, Firenze, 1974., str. 11.

7 Usp. Massimo Bontempelli, „La vispa Teresa. Saggio di Critica filosofica“, Le Cronache letterarie, Firenca, god. II., br. 53., 19. veljače 1911., str. 3. Vidii Ettore Romagnoli (ur.), Polemica carducciana, Quattrini, Firenze, 1911.

8 Walter Pedullà, „La comicità di Bontempelli“, Lilluminista, Rim, god. V. (2005.), br. 13. - 15., str. 360 . 
s dobrohotnim sažaljenjem, publika još nije poklonila Petroliniju preveliku pozornost. Pa dobro, mi se - nakon što smo redovno prisustvovali njegovim nastupima ovih dana u milanskom kazalištu Filodrammatico ne ustručavamo proglasiti Petrolinija najvećim talijanskim suvremenim umjetnikom. ${ }^{9}$

No, unatoč zajedničkim afinitetima na pretežno ideološkome, a potom i umjetničkome planu, Bontempelli će u svome prvom pravom razdoblju eksperimentalizma usmjeriti strelice ironije i parodije i protiv samoga futurističkog pokreta. Tako se u kazališnome komadu La guardia alla luna (Čuvaj se mjeseca, u našem nešto slobodnijem prijevodu) iz 1916. godine poigrava s poznatim futurističkim motom Ubijmo mjesečinu! (Uccidiamo il chiaro di luna!) s parodijsko-grotesknom intencijom. Sličnim mehanizmom poslužit će se i u Siepe a nordovest (Ograda na sjeverozapadu), prvome kazališnom komadu poslije Prvoga svjetskog rata. Iako djelo počiva na ideji prožimanja različitih prostora i vremena („compenetrazione di ambienti e di tempi diversi“), odnosno tipična futurističkog kazališnog lajtmotiva, rezultat nije apsolutni dinamizam kojemu je Marinetti težio, nego niz komičnih scena. Tvrdi, naime, Lia Lapini da „relativizam prelazi u priznanje enigme, u sugestiju metafizičke igre različitih stvarnosti koje okružuju i uvlače se u zaplet događaja." ${ }^{10}$ Ova će parodijska igra prevrtanja i revaloriziranja Marinettijeva pokreta doseći vrhunac u Intenzivnome životu (La vita intensa), prvoj zbirci kratkih priča u poraću, koji predstavlja Bontempellijev inovativni pokušaj nadilaska i arhiviranja futurizma parodirajući istovremeno tradicionalne podžanrove romana, njihove stileme kao i trivijalnu književnost. Svaka kratka priča, koju ironično naziva "pustolovnim romanom“ i dijeli na kratka poglavlja - što je samo po sebi neka vrsta petrolinijevskoga miga futurističkomu sintetizmu - predstavlja različite podžanrove suvremenoga romana (bildungsroman, psihološki, ljubavni, kriminalistički itd.) kroz prizmu parodije. Radi se o ključnome djelu Bontempellija

9 Massimo Bontempeldi, „Il più grande artista italiano contemporaneo“, Ugo Ojetti (ur.), Abbasso Petrolini, Tip. Cooperativa, Siena, 1923., str. 79. - 80.

10 Lia Lapini, Ilteatro di Bontempelli. Dallavanguardia al novecentismo, Nuove edizioni Vallecchi, Firenze, 1977., p. 114. 
kao humorista, odnosno o trenutku u kojem se njegova humoristična vena, oslanjajući se pretežito na ironiju i parodiju, kristalizira i dobiva svoj konačni oblik. ${ }^{11}$ Potvrda dolazi ne samo od autora koji ubraja Intenzivni život u svoju prvu umjetničku fazu poraća obilježenu upravo humorizmom ${ }^{12}$ nego i od njegovih suvremenika i kolega. Tako se i talijanski futurist i književnik Bruno Corra prisjeća: „Bontempelli, uvijek spretan i svjež, izjavi: 'Ja? Kako da ne! Improvizirat ću i odmah pretvoriti svoju piruetu u književnost' i tako i učini, postade prvi talijanski humorist. ${ }^{\text {“13 }}$ Bontempelli se neće odreći ovih postupaka ni u sljedećim zbirkama objavljenima u dvadesetim godinama 20. stoljeća. Unatoč različitim fazama kojima pripadaju, slažemo se s Roselenom Glielmo koja tvrdi da se zajednički nazivnik Bontempellijeva opusa nalazi u

[...] u sredstvu, istovremeno narativnom i stilističkom, koje konkretizira ideju „magičnog realizma”, koji bi se mogao definirati i kao „metafizički humorizam" (hiperrealistički), u smislu da uz pomoć ironije i/ili komičnosti (humorizma) izvrće perspektivu, priređuje neočekivana iznenađenja, izaziva efekt otuđenja i odmak. ${ }^{14}$

Koncept ironije kao sredstva umjetničkoga odmaka od vanjske stvarnosti, odnosno „spoznajnog trika koji piscu omogućuje nadilaženje prividne stvarnosti ${ }^{{ }^{15}}$, potječe iz teorijskih promišljanja o metafizičkome slikarstvu Alberta Savinija (Andree de Chirica) izloženih u članku Andioménon. Principi di valutazione dell'arte contemporanea (Anadioménon. Načela vrednovanja suvremene umjetnosti). ${ }^{16}$ Tako u Bontempellijevu

${ }^{11}$ Vidi Marinella Mascia Galateria, Tattica della sorpresa e romanzo comico di Massimo Bontempelli: saggio su La vita intensa e La vita operosa, Bulzoni, Roma, 1977.

12 Usp. Massimo Bontempelli, "Comincio ora“, L'avventura novecentista: selva polemica (1926-1938), Vallecchi, Firenze, 1938., str. 289.

${ }_{13}$ Bruno Corra, „L'Affare della Baracca“, Il cavallo di Troia, Rim, god. I. (1982.), br. 3., str. 88. Vidi Alberto Savinio, „Massimo Bontempelli“, Alessandro Tinterri (ur.), Massimo Bontempelli, Nostra Dea e altre commedie, Einaudi, Torino, 1989., str. 223. - 226.

14 Roselena Glielmo, La traversata dell'ironia: studi su Massimo Bontempelli, Alfredo Guida editore, Napoli, 1994., str. 14.

15 Isto, str. 18.

16 Za odnos Bontempellija i metafizičkoga slikarstva vidi Sandra Milanko, „Tra l'onirico e il metafisico: ultime avventure e favole metafisiche“ („Između oniričkog i metafizičkog: posljednje avanture i metafizičke bajke"), Bontempelli, l'avanguardia, il pubblico: dal futurismo 
opusu ironija nije samo sredstvo izvrtanja, otuđenja i odbijanja nepoželjnih književnih poetika i moda, već i izražavanja koncepta metafizike austrijskoga filozofa Otta Weiningera kao dubokoga smisla stvari. Taj će koncept preuzeti Giorgio de Chirico za svoje metafizičko slikarstvo, a Bontempelli će prevesti u formulaciju „smisao misterija“:

Ironija nagriza sitne priljepke stvarnosti na najtrošnijim površinama stvari i stvara pročišćenu i sjajnu atmosferu oko njihove stalne i temeljne biti, upravo onu kojoj umjetnost treba pristupiti i ostvariti. Ironija nam tako [...] omogućuje da dosegnemo dubinu etike stvari, što je vrhovna svrha umjetnosti. ${ }^{17}$

Posebno je zanimljivo da je izvršitelj tih postupaka na dijegetskoj razini, u većinskome dijelu Bontempellijevih narativnih djela dvadesetih godina, njegov neobični protagonist i pripovjedač imena Massimo. Ovaj autodijegetski pripovjedač sa svojim autorom, osim imena, dijeli i mnoge druge biografske karakteristike - obojica su pisci, kozmopoliti, putnici, zavodnici i pustolovi - tako da Massimo predstavlja i neku vrstu Bontempellijeva fikcijskog alter ega. Ono po čemu se dva Massima, fikcijski i stvarni, bitno razlikuju jest sposobnost prvoga da radi čudesa i otkriva, kako kaže Bontempelli, magični smisao svakidašnjega života. Ta nadnaravna moć, koja se razvija i sve više otkriva u zbirkama kratkih priča iz dvadesetih godina, čini Massima modernim demijurgom, odnosno još jednom verzijom deificirana čovjek ${ }^{18}$, kojima obiluje talijanska književnost prve polovice 2o. stoljeća. Dovoljno je prisjetiti se Papinijeva i Prezzolinijeva Čovjeka Boga, Marinettijeva Multipliciranoga Čovjeka zamjenjivih dijelova, nadčovjeka okultista Sama Dunna Bruna Corre i modernoga, metafizičkog čarobnjaka-umjetnika Savinija, de Chirica i Carla Carrà. Massimo odudara od njih jer skoro pa slučajno stječe svoje

alla pittura metafisica (Bontempelli, avangarda, čitateljstvo: od futurizma do metafizičkog slikarstva), doktorska disertacija, Sveučilište u Trstu, 2014., <https://www.openstarts.units. it/bitstream/10077/10152/1/tesi\%2osandra\%2omilanko.pdf>, (14. I. 2020.).

17 Massimo Bontempelli, Il neosofista e altri scritti: 1920-1922, Mondadori, Milano, 1929., str. 129.

18 Za koncept deificirana čovjeka vidi Michel Carrouges, L'avventura mistica della letteratura, Renata Gradi (prev.), Edizioni Abete, Roma, 1968. 
nadnaravne sposobnosti koje praktički ne može kontrolirati ako se ne računaju njegove latentne želje ili sama prisutnost, pri čemu često izaziva komični učinak. Dade se stoga tvrditi da on predstavlja parodiranu verziju ove umjetničke i književne figure koja potječe, u talijanskome kontekstu, iz ponešto iskrivljene recepcije ničeanske filozofije i ezoteričnih moda. Jedan njegov zanimljiv profil ponudio je i Luigi Fontanella referirajući se na Massima u zbirci kratkih priča La vita operosa (Djela$\tan \check{z} i v o t)$ :

Definirao sam protagonista Djelatnog života „antijunakom”. Doista, kad bismo ga htjeli domišljato oslikati, morali bismo zamisliti lika koji u sebi sadrži Svevinog „nesposobnog” lika, Pirandellovog „uvrnutog” Mattiju i vrlo ozbiljnog komičara Bustera Keatona (mislim, na primjer, na lika iz filma Kamerman). Od prvog (Alfonso Nitti iz romana Jedan život, ali i Emilio Brentani iz Mlade starosti) je sačuvao aktivnu lijenost i sanjivi nemar; od drugog (pirandelovskog Mattije Pascala) potragu za „podijeljenim jastvom" [...]; od trećeg (snimatelj u Kamermanu) priziva hladnu komičnost, da, ali i njegovu vrlo bistru, neospornu mentalnu geometriju. ${ }^{19}$

Neobične, bizarne, pa čak i fantastične pustolovine ovoga interesantnog književnog lika potvrđuju status humorista koji su Bontempelliju dodijelili njegovi suvremenici. To ujedno objašnjava i objavljivanje njegove zbirke kratkih priča L'eden della tartaruga (Kornjačin Eden) u već spomenutoj, izdavački zanimljivoj biblioteci Talijanski humorizam. Biblioteka žutog fauna Giuseppea Zucce. Pjesnik i humoristički pisac Giuseppe Zucca (1887. - 1959.) osnovao je izdavačku kuću Il Fauno 1926. godine u Rimu (via Nazionale 89). Prema riječima Giuseppea Iannacconea, u njoj se trebao naći „istovremeno popularan i elegantan spoj mondenih i zabavnih sastojaka elegantnog i neobuzdanog duha; sve to pod sretnim znakom fauna, rimskog božanstva, savršenog simbola senzualnosti i zavodljivosti. ${ }^{{ }^{20}}$ Lansirajući ovaj neobični izdavački pothvat,

19 Luigi Fontanella, Storia di Bontempelli: tra $i$ sofismi della ragione e le irruzioni dell'immaginazione, Longo, Ravenna, 1997., str. 24. - 25.

20 Giuseppe Iannaccone, „I ricercati delle Edizioni d'Arte Fauno“, Wuz, Milano, god. II. (2003.), br. 7., str. 18. 
mladi se pisac-izdavač obraćao širokomu čitateljstvu rastuće masovne kulture u potrazi za zabavnom književnošću koja je ujedno i umjetnički vrijedna i koja se, kao takva, mogla natjecati s novim medijima poput kina, radija i sportskih događaja. Upravo je iz toga razloga Zucca $\mathrm{u}$ humoru vidio rješenje krize književnosti dvadesetih godina u Italiji. Kako sam otkriva u kratkome tekstu Intervista allo specchio (Intervju u zrcalu):

Siva magla dosade diže se nad mnogobrojnim knjigama sedec formata koje talijanski izdavači neumorno tiskaju, širi se iz izloga knjižara, izaziva u prolaznicima prve simptome bolesti spavanja. Prolaznici se hitro udaljuju od knjižara, zaobilaze ih u širokom luku, bježe u daljinu hvatajući zrak. I imaju dobar razlog za bježanje. Za krizu (ako kriza postoji), ruku na srce, nisu odgovorni oni. Ah, književnost namrštenih ljudi koja se, da bi zavarala sebe i druge tko zna kakvom dubinom, oblači u crno, ili još gore, u sivo, sva u sivo, natmureno sivo! Kao da je, da postanemo važni i duboki, potrebno uništiti čitatelja zijevanjem i dovesti ga, nakon druge stranice, u stanje hipnoze! [...] Knjige koje će se željeti čitati! Pisce koje će se željeti čitati!To dajte čitateljima i čitatelji će dotrčati, vidjet ćete, čitatelji će kupovati, čitatelji će čitati, ponovno čitati, i tražit će još, bit će spremni slijediti vas kamo god ih želite voditi. ${ }^{21}$

Formula za uspjeh u kojoj se ujedinjuju i forma i sadržaj i koja se oslanja na spoj humora, zabave, kratkoće, privlačnih naslovnica i zanimljivih ilustracija, ali i na poznata imena suvremene talijanske književnosti, ostvarila se u Biblioteci žutog fauna, prvoj od nekoliko planiranih. ${ }^{22} \mathrm{Od}$ sveukupno 12 objavljenih naslova ${ }^{23}$ većina je bila ukrašena naslovnicom

${ }^{21} \quad$ Isto, str. 19.

${ }_{22}$ U sklopu Biblioteke ružičastog fauna izašao je samo jedan naslov više autora, Il fauno galante - vol. primo 1927. godine, u Biblioteci zlatnog fauna knjiga Levie del sole: favole Uga Tommasinija te iste godine, dok su u pripremi bile Biblioteka trobojnog fauna, Biblioteka svijetloplavog fauna i Biblioteka crvenogfauna.

${ }_{23}$ Radi se o sljedećim naslovima: 1. Giuseppe Zucca, L’uomo dell'amazzone, 2. Luigi Antonelli, La donna in vetrina, 3 . Luciano Folgore, Mia cugina la luna, 4. Massimo Bontempelli, Leden della tartaruga, 5. Amalia Guglielminetti, Il pigiama del moralista, 6. Trilussa, Picchiabbò, 7. Achille Campanile, L'inventore del cavallo, 8. Antonio Beltramelli, La locanda al Bove Solare, 9. Orio Vergani, Asso piglia tutto, 10. Filippo Tommaso Marinetti, Scatole d'amore in conserva, 11. Eugenio Giovannetti, Sirene in vacanza, 12. Giuseppe Zucca, I cavalieri del tartufo. 
Vinicia Paladinija, talijanskoga likovnog umjetnika bliska talijanskoj avangardi, koja je prikazivala kazalište marioneta sa stražnjim dijelom fauna u pozadini scene. Za razliku od njih, Marinettijeva zbirka kratkih priča Scatole d'amore in conserva (Limene konzerve ljubavi) ukrašena je izvrsnom ilustracijom talijanskoga slikara i ilustratora Piera Bernardinija koja prikazuje poluotvorenu limenu konzervu živih boja imena Ekstrakt ljubavi, anticipirajući tako Andyja Warhola za dobrih trideset pet godina. Na biblioteci su sudjelovali najbolji ilustratori toga razdoblja poput Enrica Sacchettija, ilustratora časopisa La lettura i same Bontempellijeve zbirke, ili pak talijanskoga slikara Ive Pannaggija, ilustratora Marinettijeve zbirke. Reakcije kritičara, ili zbog ilustracija ili zbog samoga sadržaja, bile su iznimno pozitivne, o čemu svjedoči i književni kritičar i pisac Fernando Palazzi na unutrašnjoj strani naslovnice Kornjačina Edena: „Treba priznati da je Giuseppe Zucca, osmislivši ovu biblioteku, dobro pogodio. Puno očekujem od ovog Žutog fauna: i ako će talijansku književnost učiniti zabavnijom i manje arogantnom, onda će donijeti više dobra nego što je to njezin pokretač očekivao. ${ }^{24}$ Čak se i izdavač Angelo Fortunato Formiggini, ${ }^{25}$ autor strogoga Dizionarietto rompitascabile degli Editori Italiani, compilato da uno dei suddetti (Mali gnjavatorskodžepni rječnik talijanskih izdavača, koji je sastavio jedan od njih), prisjetio ove izdavačke kuće sa stanovitom naklonošću: „FAUNO - To je zabavni izdavački pothvat koji je niknuo iz Zuccove ('Tikva') tikve, prvo u obliku Žutog fauna, a sad u obliku Galantnog fauna. ${ }^{{ }_{26} 6}$ Osim dimenzija i cijene (format A5 i oko 100 stranica po cijeni od 4 lire), naslovi Žutoga fauna imali su i istu strukturu:

Svaka se knjiga otvara stranicom koja prethodi naslovnoj i sadrži „Policu“ autora knjige: na njoj se nalaze, u obliku naslaganih knjiga, autorovi

${ }^{24}$ M. BONTEMPELLI, L'Eden della tartaruga.

25 S izdavačkom kućom Formiggini Zucca je bio objavio zbirku pjesama Io. Liriche (Ja. Pjesme) u biblioteci Poeti italiani del XX secolo (Talijanski pjesnici XX. stoljeća) 1919. godine te La piega nei calzoni - stacco qualche pagina gaia dal mio taccuino di guerra (Nabor na hlačama - kidam koju zabavnu stranicu iz svog ratnog dnevnika) u biblioteci Simpaticissima 1920. godine.

26 Angelo Fortunato Formiggini,. Dizionarietto rompitascabile degli Editori Italiani, compilato da uno dei suddetti, A. F. Formíggini Editore, Roma, 1928., str. 17. 
objavljeni naslovi. Nakon naslovne stranice slijedi katanac čiji ključ čuvaju tri anđela, a znači „Književno vlasništvo“; na sljedećoj stranici, naslovljenoj Galerija Fauna, nalazi se zrcalo s karikaturom autora na njemu, a ispod odgovor autora na pitanje (uvijek isto) Giuseppea Zucce: „Što je to, po vama, humor" zatim se najavljuju skorašnji naslovi, odnosno oni „U tisku“; i naposljetku dolazi tekst, uvijek obogaćen ukrasima i ilustracijama. Na kraju knjige je i Ogledalo Fauna (autokarikatura ilustratora), Sadržaj i pokoja reklama: ... ${ }^{27}$

Ono što Bontempellijevu zbirku, koja je dosad prošla neopaženo kod talijanskih, ali i stranih kritičara, čini posebno zanimljivom nije samo humoristični element koji će obilježiti i sljedeće zbirke kratkih priča, već i izdavačka priča u pozadini. Kornjačin Eden rezultat je montaže koju Bontempelli provodi u nizu zbirki kratkih priča dvadesetih godina ubacujući dijelove priča ili cijele priče, već objavljene u prijašnjim zbirkama ili časopisima, s namjerom formiranja i osnaživanja rastućega makroteksta. Zbirka se, naime, kronološki nalazi među ostalim zbirkama u kojima se javlja već spomenuti autodijegetski pripovjedač Massimo te, uz već objavljene priče, sadrži i poneke neobjavljene koje će se savršeno uklopiti u buduću produkciju zahvaljujući upravo ovim intertekstualnim poveznicama.

Zbirku čini devet kratkih priča, objavljenih i neobjavljenih, koje se i tematski razlikuju jer je u svim dotad neobjavljenim pričama pripovjedač u prvome licu, koji u mnogočemu upućuje na autodijegetskoga pripovjedača prijašnjih zbirki, dok su objavljene priče preuzete iz zbirke Teatrino (Malo kazalište). ${ }^{28}$ Te se zbirke, naime, Bontempelli odrekao zajedno s mnogim drugim djelima objavljenima prije Prvoga svjetskog rata jer nisu bile u skladu s umjetničkom obnovom koju je začetnik talijanskoga magičnog realizma započeo čim se vratio iz rata. Kratke priče Grandezza e decadenza (Veličina i dekadencija), L'uomo delle collezioni (Čovjek sa zbirkama) i Memorie di unimpiegato abitudinario (Sjećanja zaposlenika sklonog navikama) iz zbirke Kornjačin Eden istovjetne su pričama Barba (Brada), Il collezionista (Kolekcionar) i L'unicasera

${ }_{27}$ G. IANNACCONE, $n . d j$., str. 18.

28 Usp. Massimo Bontempelli, Teatrino,Società editoriale italiana, Milano, 1917. 
ovvero La virtù mal ricompensata (Jedina večer odnosno Slabo cijenjena vrlina) iz zbirke Teatrino. Te će iste priče biti ponovno objavljene s prvotnim naslovima u zbirci Primi racconti (1905-1914), ${ }^{29}$ najavljenoj upravo u spomenutoj sekciji „U tisku“ Kornjačina Edena. Među već objavljenim pričama može se ubrojiti i priča Come tutti gli altri (Poput svih drugih) koja je bila izašla u časopisu La Lettura pod naslovom Re a passeggio $^{30}$ (Kralj $u$ šetnji), popraćena i ovoga puta ilustracijama Enrica Sacchettija.

Neobjavljene priče, osim što imaju autodijegetskoga pripovjedača koji neodoljivo podsjeća na već spomenutoga Massima, bit će uvrštene i u sljedeće zbirke kratkih priča, a može ih se podijeliti u dvije tematske cjeline. U onu prvu spadaju dvije humoristički najuspjelije priče u zbirci, Racconto con molto pathos (Priča s mnogo patosa) i All'americana (Američka), koje će kasnije tvoriti drugo i treće poglavlje obiju verzija zbirke Mia vita morte e miracoli ${ }^{11}$ (Moj život smrt $i$ čudesa). U prvoj od dviju priča, s kojom se zbirka i otvara, autodijegetski pripovjedač zaposlen je u bračnoj agenciji, u odjelu „Udovci i udovice“. Učinak komičnoga postiže se neočekivanim kontrastom u karakteru glavnoga lika, privlačna i dobrostojećega, ali istovremeno jeziva i groteskna udovca koji gaji morbidni kult svoje preminule žene (i općenito smrti i posmrtnih rituala), ali je i u potrazi za novom ženom, isto udovicom i s istim kultom preminuloga muža. Autodijegetski pripovjedač, koji je posrednik u upoznavanju i sklapanju brakova, dovede mu novu kandidatkinju koja, naime, nakon upoznavanja niza gesti i običaja udovca doslovno pobjegne. I druga priča, All'americana, odvija se u poslovnome svijetu. Ovoga se puta autodijegetski pripovjedač bavi poslovnom korespondencijom zajedno s lijepom daktilografkinjom Albom Lucani i njihovim šefom

29 Usp. Massimo Bontempelli, Primi racconti (1905-1914), Mondadori, Milano, 1934.

3o Usp. Massimo Bontempelli, „Re a passeggio”, La Lettura, Milano, god. XXIV., br. 6., 1. lipnja 1924., str. 409. - 414.

${ }_{31}$ Usp. Massimo Bontempelli, Mestieri varii della mia adolescenza e prima giovinezza Sei mesi d'amore di Virgilio Capò i Mi occupo in una agenzia di matrimoni - La delusione d'un vedovo patetico, Mia vita morte e miracoli, A. Stock, Roma, 1931., Isti, Miracoli (19231929), Mondadori, Milano, 1938., ponovno tiskano u Massimo Bontempelli, Romanzi e racconti, Paola Masino (ur.), Mondadori, Milano, 1961. 
Virigilijem Capòm. Bontempelli već samim naslovom izaziva komični učinak aludirajući na Capòvo udvaranje Albi (poigravajući se, između ostaloga, s figurom daktilografkinje i ljubavnim pričama lijepe i skromne zaposlenice i njezina šefa iz ondašnjih američkih filmova), koje se odvija $\mathrm{u}$ tome istom poslovnom ambijentu. On joj, naime, diktira privatna pisma u uredu, naslovljena na nju, i to pred očima pripovjedača koji pozorno prati neobičnost situacije. Udvaranje se, dakle, ostvaruje uz nezaobilazan komični učinak jer nalikuje na svaku drugu poslovnu korespondenciju, ne narušavajući ni formalni odnos između zaposlenice i njezina šefa.

U drugu tematsku cjelinu spadaju dotad neobjavljene priče Vera storia del mondo (Prava priča o svijetu), Pittoresca (Slikovita) i Altre cose del Duiblar (Druge stvari u Duiblaru) koje predstavljaju događaje i susrete koji su se dogodili autodijegetskomu pripovjedaču tijekom njegova putovanja u mjesta na visoravni Duiblar - onoj istoj na kojoj se odvija i metafizička bajka Eva ultima ${ }^{32}$ (Posljednja Eva) objavljena tri godine prije. Upravo je to jedna od već spomenutih intertekstualnih poveznica koje Bontempelli uvodi iz zbirke u zbirku pridonoseći njihovu jedinstvu i serijalnosti, a taj će se postupak potvrditi i u sljedećim djelima i njihovim razvrstavanjima u sklopu različitih izdavačkih pothvata Arnalda Mondadorija, glavnoga Bontempellijevog izdavača. Vera storia del mondo ponovno će se pojaviti u objema verzijama zbirke Stato di gra$z_{i a^{33}}$ (Stanje blaženstva), Pittoresca samo u prvoj verziji s naslovom Pittore a quel paese (Slikar u tom mjestu), dok će Altrecose del Duiblar biti uvrštena i u prvu verziju zbirke Stato di grazia (pod naslovom Costumi di quel paese (Običaji tog mjesta)) i u četvrto poglavlje druge verzije zbirke Mia vita morte e miracoli (Mio viaggio a Duiblar - Strano pudore di quell agente; Moje putovanje u Duiblar - Čudna čednost tih ljudi).

Kao što se može vidjeti iz „geneološke“ analize ovih priča, zbirka humorističkih kratkih priča L'Eden della tartaruga predstavlja jedinstven slučaj u okviru Bontempellijevih pripovjednih djela jer se sastoji od

32 Usp. Massimo Bontempelli, Eva ultima, Alberto Stock, Roma, 1923.

33 Usp. Massimo Bontempelli, Stato di grazia, Alberto Stock, Roma, 1931.; Isti, Stato di grazia, Sansoni, Firenze, 1942. 
objavljenih i neobjavljenih priča koje će biti uključene i u sljedeće zbirke, ujedinjujući ih u makrotekst, ponekad i pod krinkom neobjavljena teksta. Zbirka neće biti spomenuta u popisu objavljenih djela u prvoj verziji zbirke Mia vita morte e miracoli, iako, kao što smo vidjeli, ta fikcijska autobiografija autodijegetskoga pripovjedača Massima sadrži dvije priče iz Bontempellijeve zbirke u sklopu biblioteke Žuti faun. Budući da će Zuccova izdavačka kuća prestati s radom samo godinu dana nakon osnivanja, razumljivo je što je Bontempelli odlučio reciklirati pojedine priče u sljedeće zbirke. Osim toga, i jedan drugi Zuccov autor postupio je na sličan način: Marinettijeva zbirka sadrži samo jednu dotad neobjavljenu priču, dok su sve ostale već bile objavljene u časopisima ili prijašnjim zbirkama. No, u Bontempellijevu slučaju ne radi se samo o pametnome izdavačkom potezu ponovnoga lansiranja starih i novih kratkih priča, već i o pokušaju nadovezivanja na prijašnja književna djela i najavljivanja onih sljedećih.

\section{Literatura}

- Bontempelli, Massimo, Eva ultima, Alberto Stock, Roma, 1923.

- Bontempelli, Massimo, Il neosofista e altri scritti: 1920-1922, Mondadori, Milano, 1929.

- Bontempelli, Massimo, „Il più grande artista italiano contemporaneo", Ojetti, Ugo (ur.), Abbasso Petrolini, Tip. Cooperativa, Siena, 1923., str. 79. -80 .

- Bontempelli, Massimo, L'avventura novecentista: selva polemica (1926-1938), Vallecchi, Firenze, 1938.

- B. [ONTEMPelli], M. [Assimo], „La festuca“, Le Cronache Letterarie, Firenca, god. II., br. 54., 26. veljače 1911., str. 3.

- Bontempelli,Massimo, „La vispa Teresa. Saggio di Critica filosofica", Le Cronache letterarie, Firenca, god. II., br. 53., 19. veljače 1911.,str. 3.

- Bontempelli, Massimo, L'Eden della tartaruga, Edizioni d'arte Fauno, Roma, 1926. 
- Bontempelli, Massimo, Miracoli (1923-1929), Mondadori, Milano, 1938.

- Bontempelli Massimo, Nostra Dea e altre commedie, TinTerri, Alessandro (ur.) Einuadi, Torino, 1989.

- Bontempelli, Massimo, Primi racconti (1905-1914), Mondadori, Milano, 1934.

- Bontempelli, Massimo, „Re a passeggio”, La Lettura, Milano, god. XXIV., br. 6., 1. lipnja 1924., str. 409. - 414.

- Bontempelli, Massimo, Romanzi e racconti, Masino, Paola (ur.) Mondadori, Milano, 1961.

- Bontempelli, Massimo, Socrate moderno, Lattes, Torino, 1908.

- Bontempelli, Massimo, Stato di grazia, Alberto Stock, Roma, 1931.

- Bontempelli, Massimo, Stato di grazia, Sansoni, Firenze, 1942.

- Bontempelli, Massimo, Teatrino, Società editoriale italiana, Milano, 1917.

- Carrouges, Michel, L'avventura mistica della letteratura, GraDI, Renata (prev.) Edizioni Abete, Roma, 1968.

- Cigliana, Simona, ,Gli antidoti della ragione: classicismo, ironia e metafisica", Bollettino '9oo, br. 1. -2., 2010., <https://bollgoo.it/ numeri/2010-i/Cigliana.html>, (14. I. 2020).

- Corra, Bruno, „L'Affare della Baracca“, Il cavallo di Troia, Rim, god. I. (1982.), br. 3., str. 87. - 89 .

- Fontanella, Luigi, Storia di Bontempelli: tra i sofismi della ragione e le irruzioni dell'immaginazione, Longo, Ravenna, 1997.

- Formiggini, Angelo Fortunato, Dizionarietto rompitascabile degli Editori Italiani, compilato da uno dei suddetti, A. F. Formíggini Editore, Roma, 1928.

- Glielmo, Roselena, La traversata dellironia: studi su Massimo Bontempelli, Alfredo Guida editore, Napoli, 1994. 
- IANNACCONe, Giuseppe, „I ricercati delle Edizioni d'Arte Fauno“, Wuz, Milano, god. II. (2003.), br. 7., str. 16. - 21.

- Lapini, Lia, Il teatro di Bontempelli. Dall'avanguardia al novecentismo, Nuove edizioni Vallecchi, Firenze, 1977.

- Lipparini, Giuseppe, „Romanzi e novelle“, Il Marzocco, Firenca, god. XIII., br. 27., 5. srpnja 1908., str. 2.

- Mascia Galateria, Marinella, Tattica della sorpresa e romanzo comico di Massimo Bontempelli: saggio su La vita intensa e La vita operosa, Bulzoni, Roma, 1977.

- Milanko, Sandra, Bontempelli, l'avanguardia, il pubblico: dal futurismo alla pittura metafisica, doktorska disertacija, Sveučilište u Trstu, 2014., <https://www.openstarts.units.it/bitstream/10077/10152/1/tesi\%2osandra\%2omilanko.pdf>, (14. I. 2020.).

- Pedullà, Walter „La comicità di Bontempelli“, Lílluminista, Rim, god. V (2005.), br. 13. - 15., str. 351. - 376.

- Romagnoli, Ettore (ur.), Polemica carducciana, Quattrini, Firenze, 1911.

- Tempesti, Fernando, Massimo Bontempelli, La Nuova Italia, Firenze, 1974 . 


\section{HUMOURIST BONTEMPELLI AND COLLECTION OF SHORT STORIES L'EDEN DELLA TARTARUGA}

\section{Abstract}

Known primarily as the founder of Italian magic realism, Italian writer Massimo Bontempelli (1878-1960) was also appreciated in the inner circle of $2 \mathrm{O}^{\text {th }}$ century Italian writers and critics for his exquisite vein of humour present throughout his literary work in shape of irony, parody, satire and even grotesque. Starting from his very first collection of short stories Socrate moderno (1908) to his mature literary works between the 1920 s and 1930s, Bontempelli perfectionated his humourist expression. What comes as confirmation of these claims are not only his short stories from that period, panoramically reviewed from this specific point of view, but also L'Eden della tartaruga (1926), Bontempelli's rare collection of short stories practically forgotten by the critics and the readership, included in an interesting publishing experiment, a book series of humorous short story collections called Umorismo italiano. Serie del fauno giallo edited by Giuseppe Zucca. In the second part of the article the collection is described in details and placed within his oeuvre thus revealing Bontempelli's own publishing venture: uniting published and unpublished short stories in order to connect his previous and future literary works into a macrotext.

Keywords: humour; irony; parody; magic realism; short story; book series 